\title{
The Influence Of Boards Of Directors' Characteristics On Strategic Decision- Making: Evidence From Greek Companies
}

Maria Elisavet Balta, Brunel University, UK Adrian Woods, Brunel University, UK Keith Dickson, Brunel University, UK

\begin{abstract}
This study explores the influence Boards of Directors' demographic characteristics on the process of making strategic decisions. Empirical testing is based on a sample of 105 Greek companies listed on the Athens Stock Exchange. The results suggest that educational level affect both the financial reporting and the hierarchical decentralisation in the strategic decision-making process. Also, functional background of executives was found to be related with financial reporting. However, the educational specialty did not appear to have any significant influence on the strategic decision-making process. In light of these findings, implications for practitioners are made and avenues for future research are suggested.
\end{abstract}

Keywords: Boards of Directors, demographic characteristics, strategic decision-making process, Greece

\section{INTRODUCTION}

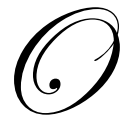

ver the last decades, a new research on how executives influence strategic decisions and organisational outcomes has received a great attention in the area of strategic management and organisational studies. In the strategic management research, executives play a dominant role in formulating corporate strategy and in determining the direction of the firm (Westphal and Fredrickson, 2001). In the existing literature two themes have been emerged, first, the role of top management (Lewin and Stephens, 1994) and second, the process of making strategic decisions (Rajapogopalan, Rasheed and Datta, 1993; Papadakis and Barwise, 1998).

Most of the studies have been grounded in the upper echelons' perspective proposed by Hambrick and Mason (1984) and attempted to examine how the managerial characteristics including cognitive skills, experience, and knowledge, personality traits affect several content strategic decisions among them diversification, resource management, innovation and change (Finkelstein and Hambrick, 1996; Herrmann and Datta, 2006). Although the body of research over the last decades focus on content research, our knowledge of strategic decision-making processes is limited and is based so far on theoretical studies (e.g. Bateman and Zeithaml, 1989; Langley, 1990; Pettigrew, 1990). Therefore, there is an increased need for an integrative research which explicitly considers the impact of context on strategic decision-making processes (Bateman and Zeithaml, 1989; Rajagopalan et al., 1993; Bryson and Bromiley, 1993; Papadakis et al., 1998). The present study attempts to contribute to this area by examining empirically a number of strategic decision making processes and their determinants.

The current study aims to examine how the characteristics of Boards of Directors' influence the strategic decision-making process of financial reporting and hierarchical decentralisation. The paper proposes an integrative framework in an effort to investigate the key factors of strategic decisions in a relative new empirical context; Greece. The paper is organized as follows: in the first section, we review the literature and formulate research hypotheses. Next, we describe our methodology and the cultural context for the study. The third section presents our results and discusses them, and the final section explores their implications and provides insights for further research. 


\section{LITERATURE REVIEW}

Strategy as a concept has its roots in business policy (e.g. Andrews, 1971; Hofer, 1975) as well as in organisational theory (e.g. Aldrich and Pfeffer, 1976; Child, 1972). Strategy is regarded as a set of decisions that a) guide the organisation according to the environment, b) affect the internal structure and processes and c) consequently, its performance. Strategy is the outcome of formal planning; an analytical process, which establishes long term objectives, a process usually initiated by Top Management and undertaken by staff strategists (Ansoff, 1965; Chandler, 1962). Strategic process includes strategic analysis, strategic choice and strategic implementation (Andersen, 2000). Strategic analysis is concerned with the strategic position of the organisation in terms of internal and external environment in which it operates and the expectations and influences of stakeholders. Strategic choice deals with identifying and understanding stakeholders' expectations, strategic vision and mission, portfolio management and financial capabilities. Finally, strategic implementation refers to the translation of strategy into organisational action through organisational structure and design, resource planning and the management of strategic change (Andersen, 2000).

Dean and Sharfman (1996, pp. 379-380) describe strategic decisions as: "committing substantial resources, setting precedents, and creating waves of lesser decisions (Mintzberg et al. 1976) as ill-structured, non-routine and complex (Schwenk, 1988); and as substantial, unusual and all pervading (Hickson et. al., 1986)". Top management team is responsible for the strategic decisions, which can be either formal or informal (Penning, 1985) and they reflect the interaction between an organisation and its environment (Ginsberg, 1988). They deal with issues that are essential for the survival of an organisation rather than issues, which lend themselves to routine strategic-making (Stahl and Grigsby, 1992). Strategic decision-making has received increased attention among scholars and business practitioners (Ireland and Miller, 2004). Strategic decision-making has been distinguished into two broad categories: content research and process research. Content research deals with issues of strategy content such as portfolio management, diversification, mergers and the alignment of firm strategies with environmental characteristics (Elbanna, 2006, p. 2). However, process research deals with the process by which a strategic decision is made and implemented and the factors, which affect it (Elbanna, 2006, p. 2). Although most of the studies deal with content issues, equivalent attention has to be placed on process research. Hitt and Tyler (1991) argued that a combination of different dimensions on the strategic decision-making process will contribute to a better understanding of the factors that influence the strategic decision-making process. Previous work on strategic decision-making processes so far, put emphasis on rationality and comprehensiveness of strategic decisions (Elbanna and Child, 2007; Papadakis and Barwise, 2002), the current study will shed light on two under researched strategic decision-making processes of financial reporting and hierarchical decentralisation. The current study examines the strategic decision-making processes from the strategic choice perspective.

\section{Strategic Choice Perspective}

Strategic choice perspective focuses on the role and attributes of decision makers. It reflects the idiosyncrasies of decision-makers (Child, 1972; Cyert and March, 1963). Strategic choice supporters highlight the effect of managers on strategic decisions. They argue that individuals take decisions that depend on prior processes of human perception and evaluation (Child, 1972). Schwenk (1989) claimed that individual characteristics affect the heuristic and cognitive maps that are used to make strategic decisions and suggested three variable categories of individual differences: cognitive style, demographic factors and personality traits. The strategic choice paradigm (Child, 1972) postulates that key decision-makers have considerable control over an organisation's future direction. In the upper echelons perspective, Hambrick and Mason (1984) introduced the coalignment between strategy and managerial characteristics. It provides a framework, which examines how managers influence organisational outcomes.

Although the existing literature supports the link between executives and corporate strategies (Miller and Toulouse, 1986; Finkelstein and Hambrick, 1990), there is no extensive empirical work that examines the relationship between managerial characteristics and strategic-decision making processes (Bantel, 1993, Smith et al., 1994). As Rajagopalan et al., 1993, p. 364) point out "research relating organisational factors such top management team (TMT) characteristics to strategic decision making processes is limited". Therefore, the influence of Boards of Directors on the strategic decision-making process remains unclear. Lyles and Mitroff (1980, p. 117) 
argued that: "It is still not clear what influence managerial characteristics have on the organisational problem formulation process. The results of the study indicate that these characteristics were not significant. This might indicate that the problem formulation process is at an organizational rather than an individual level, in which case individual managers might not have a strong influence on the process...". Many researchers argue that managers' characteristics do not play a dominant role in strategic decision-making (Lieberson and O'Connor, 1972; Hannan and Freeman, 1977). Stein (1980, p. 332) claimed that "leadership does not constitute a meaningful contextual domain influencing strategic procedures". Whereas, a study conducted by Hitt and Tyler (1991) showed that the CEO's demographic characteristics to have an impact on the strategic decision-making processes. The undertaking study aims to examine the effect of demographic characteristics on the strategic decision-making on financial reporting and hierarchical decentralisation. The aforementioned characteristics have rarely been empirically examined before in strategic decision-making literature.

\section{Boards of Directors' Demographic Characteristics and Strategic Decision-Making Process}

Organisational demography is conceptualised as the distribution of organisational members along any demographic traits or any set of demographic traits (Pfeffer, 1983). Pfeffer (1983, p. 348) argued that "demography is an important, causal variable that affects a number of intervening variables and processes and, through them, $a$ number of organisational outcomes." Upper echelon theory suggests that the demographic characteristics of managers bring a cognitive base and values to the decision-making process that restricts their field of vision. The demographic characteristics that will be examined in this study with respect to their effect of strategic decisionmaking are; educational level, specialty and functional background of Greek executives.

\section{Education}

Educational level is viewed as an indicator of executives' knowledge, cognitive orientation and skill base (Hambrick \& Mason, 1984). Education level shows the degree of people's information analysis (Dollinger, 1984). Educated CEOs are likely to demand detailed information and extensive financial reporting (Bantel, 1993). In a sample of Greek manufacturing firms, Papadakis, Lioukas and Chambers (1998) found that education level to be positively associated with financial reporting. The empirical findings of Papadakis and Barwise (2002) indicate that CEO characteristics (education) as well as TMT characteristics (education and competitive aggressiveness) are related to the degree of hierarchical decentralization. Finally, in a study conducted by Goll and Rasheed (2005), they found a significant and positive relationship between educational level and rational decision-making. The relationship between managerial characteristics and the strategic decision-making process has led to mixed findings. In addition, Papadakis and Barwise (1997) pointed out the problem of identifying key influences on the strategic decision-making process. Drawing from these research conclusions it is possible to articulate grounded hypotheses which states that:

H1: Educated executives pursue financial reporting and hierarchical decentralisation in the strategic decisionmaking.

\section{Educational Specialization}

Educational specialization reflects an individual's cognitive style and personality (Holland, 1973). Hitt and Tyler (1991) argued that certain types of educational specialty influence the strategic decision-making process and strategic change. Executives with formal education training in sciences and engineering related specialty have a better understanding of technology advancements and therefore, encourage cooperative opportunities. Heilmeier (1993) suggested that technically trained executives are aware of relevant technologies and are able to predict, comprehend and anticipate long-term change. In contrast, executives with only a formal management education are more likely to pursue short-term performance goals and long-term asset building compared to executives with other educational backgrounds (Hambrick and Mason, 1984). In general education and in particular professional management education focuses more on application of analytical techniques rather than risk-prone idiosyncratic judgments of "self-made" executives (Goll and Rasheed, 2005, p.1005). Thus, we state that: 
H2: Educational specialty of executives influences the strategic decision-making process of financial reporting and hierarchical decentralization.

\section{Functional Background}

Functional Background represents an important aspect of an individual's experience base and as a result a key indicator of the type of skills and cognition that the executive brings to his/her job (Rajagopalan and Datta, 1996). Dearborn and Simon (1958) concluded that managers with different functional backgrounds differ in their attitudes, knowledge and perspectives and therefore, different strategic choices. Functional background is a lens through which business situations are viewed (Guthrie and Datta, 1997). Functional backgrounds indicate the way and how strategic decisions are made (Hitt and Ireland, 1985).

Empirical studies have identified systematic relationships between managers' functional experience and firm's strategy. Thomas et al., (1991) have found strong associations between CEO functional experience and strategic orientation. In addition, Smith and White (1987) observed significant relationships between new CEOs functional background and firm's diversification strategies.

Hambrick and Mason (1984) have distinguished functional background into two broad categories the "output" functions and the "throughput" functions. The "output" functions include functional areas relating to marketing, sales, merchandising as well as product research and development (R\&D) and entrepreneurship, which emphasize on growth, search for new opportunities and are responsible for monitoring and adjusting products. On the other hand, "throughput functions" include areas of productions/operations, engineering finance and accounting, which aim to the increase the efficiency in the transformation process.

This classification provides a linkage between functional background and organisational decision-making. The organisation's strategy partly determines the types of functional background that are essential for the firm's success (Hitt, Ireland and Palia, 1982). For instance, executives with backgrounds in R\&D are associated with progress, invention and improvement (Wiersema and Bantel, 1992) as well as with differentiation and low-cost strategy (Govindarajan, 1989). On the other hand, throughput backgrounds are important in industries which are characterized by high capital intensity or concentration and lower growth (Rajagopalan and Datta, 1996). Previous studies have focused on the influence of managerial functional background to content strategic decisions but with mixed results. This study attempts to investigate the effect of functional background of managers to the strategic decision-making process. Therefore, we put forward the following hypothesis:

H3: The executives' functional background is associated with the strategic decision-making of financial reporting and hierarchical decentralisation

\section{Theoretical Framework of the Influence of Board of Directors' Demographic Characteristics on Strategic Decision-Making Process}

Based on the theoretical framework developed by Hambrick amd Mason (1984) that examines the predisposition of executives' characteristics on strategic decisions, the study proposes a theoretical model that examines the effect of demographic attributes on two rarely examined strategic decision-making processes namely financial reporting and hierarchical decentralisation. The theoretical model underlying the study is presented in Figure 1

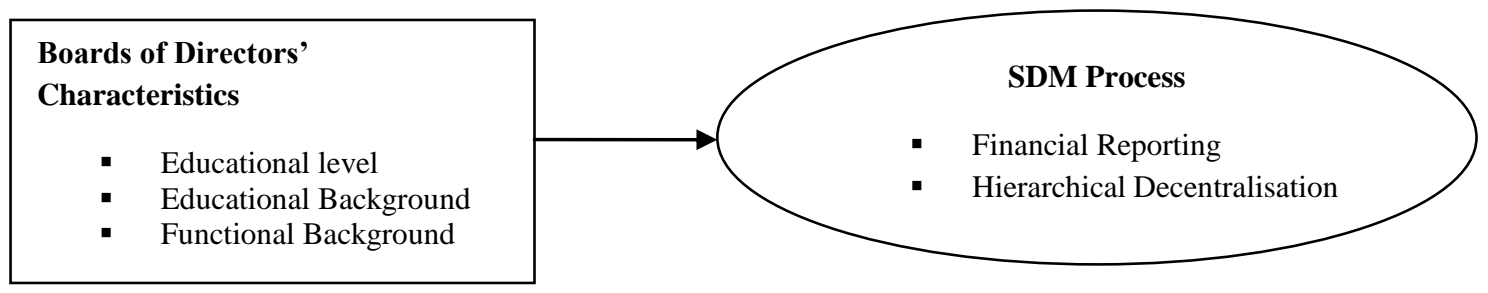

Figure 1: An integrative model of the influential factors of the SDM process. 


\section{CULTURAL CONTEXT}

Greece is a developed country, a member of the European Union since 1981 and a member of the Economic and Monetary Union (EMU) of the European Union (EU) since 2001.The management of Greek organisations is underdeveloped compared to other national partners (EEDE, 1986). Hofstede (1980) found that Greece was characterised by the highest "uncertainty avoidance" index as well as by a masculine culture. He suggested that the need for security and status are important for Greeks. Mead (1994) and Triandis, Vassiliou and Nassiakou (1968) have mentioned that the need for self-esteem is strong in Greeks which derives from the prominent cultural value known as philotimo (cooperative and self-sacrificing behaviour). The majority of empirical studies have been carried out in Greece a few decades ago, in a period of low levels of industrialization, growth rate and level of disposable income. In addition, during this period Greece was experiencing high levels of unemployment, immigration and low educational level among employees, managers and entrepreneurs. However, the situation in Greece has changed since Greece joined the European Union and the levels of education, development, political stability and democracy have been improved. Bourantas et al. (1987) mentioned that there are significant changes in the needs of Greeks suggesting that Greeks place enormous attention of on the "ego needs" of self-esteem and status through wealth.

Regarding the Greek leadership styles, Hofstede (1976) showed that Greek executives preferred the consultative style (i.e., 70 percent of respondents preferred the consultative style, 18 percent the participative style, 12 percent the persuasive style and 0 percent the autocratic). Triandis et al. (1968) suggested two central attributes of the Greek national character are extreme competitiveness and an unusual response to people in authority. Within the in-group (members of a person's immediate family, friends) people with authority and cooperative behaviour are welcome compared to those within out-group people with suspicious, hostile and extremely competitive behaviour. The strategic decision-making styles of Greek companies are less comprehensive/rational and less formalised, used less lateral communication and experience and more problem-solving dissension. Others (e.g. Kanellopoulos, 1991; Papalexandris, 1988) have documented a lack of wide diffusion of modern management methods and systems such as formal structures, planning and control systems, human resource management systems and management information systems. Bourantas and Papadakis (1997, pp. 23-24) stated "We would rather characterize Greek management as a Western-type management style that has not yet reached a high level of modernization and adoption of scientific and analytical methods and techniques". They imply that Greek management differs in the degree of modernisation and professionalism of management functions, management systems and professional knowledge and skills. Greek management compared to other European countries does not have any different model but a different degree of development.

\section{METHODOLOGY}

\section{Sample}

To test our hypotheses we used data of Greek firms that were listed on the Athens Stock Exchange during the period 2006-2007. Companies that were de-listed were excluded as well as companies with missing data, yielding a sample frame of 290 firms. We sent questionnaire to board members of 290 firms. One hundred and five executives completed the questionnaire for an overall response rate $39.6 \%$.

\section{Measurements}

Independent variables: Educational background is measured by using a 4-level scale: 1=high school, $2=$ bachelor's degree, $3=$ master's degree and 4=doctoral degree. In addition, respondents were asked to indicate the area of highest educational background from eight modified disciplines: engineering, sciences, business administration, business, social sciences-economics-sociology, marketing, civil engineering and other. Functional background is defined as the area in which executives had spent more years (Carpenter and Fredrickson, 2001; Michael and Hambrick, 1992). In this study, respondents were asked to specify their functional background within the following seven categories: finance treasurer, general management, information systems, marketing/sales/customer services, accounting/controller, manufacturing and sales and engineering. 
Dependent variables: The dependent variable is the strategic decision-making process of financial reporting and hierarchical decentralisation. The financial reporting activities consist of five items: 1. use of NPV-IRR methods, 2. use of net present value as capital budgeting method, 3. inclusion of pro forma financial statements, 4. detailed cost studies, 5. incorporation of the strategic decision into companywide financial plans (Papadakis, Lioukas and Chambers, 1998; March, Barwise, Thomas and Wensley, 1988). The measurement scale ranges from "1" strongly disagree to "7" strongly agree. Hierarchical decentralisation represents the extent of vertical decentralisation of the decision-making during all the phases of the process. Hierarchical levels include owner and/or main shareholder, CEO, first-level directors, middle management and lower management.

\section{EMPIRICAL FINDINGS}

Appendix Table 1 presents the factors that have been extracted from strategic decision-making process characteristics. Also, Table 1 presents a summary of the construct reliability measurements. Kline (1999) notes that the acceptable value for Cronbach's alpha is between 0.7 and 0.9 . All scales are found to satisfy this reliability criterion with Cronbach's alpha coefficients ranging from 0.818 to 0.706 . The principal component analysis with a varimax rotation regarding the strategic decision-making process falls into two distinctive categories: 1) financial reporting and 2) hierarchical decentralization. Principal component analysis allows identifying whether they are particular dimensions of the concepts of the strategic decision-making process. Specific variables may be observed as being strongly associated with one another, thereby indicating the existence of a dimension of a factor. A summary of the factor loadings for principal component analysis of the several stages of strategic decision-making process can also be found in Table 2 .

Table 3 presents the findings from the General Linear Model (GLM) analysis. GLM analysis allows us to analyse the variance by splitting the data into levels and running the analysis by using categorical data that define the levels. The results indicate that the executives' educational level affect the strategic decision-making process of financial reporting and hierarchical decentralisation. Also, the functional background was found to be associated with the financial reporting of strategic decisions.

The first hypothesis suggests that the higher the executives' educational level the more likely they will be to adopt financial reporting and hierarchical decentralisation in the strategic decisions. Education level is regarded as an indicator of knowledge and skill base (Hambrick and Mason, 1984). It has been associated with tolerance for ambiguity, capacity for information processing and ability to identify and analyse alternative solutions (Wiersema and Bantel, 1992). Executives who have obtained a higher general educational level or management educational level focus more on the analytical techniques in the strategic decision-making process compared to "self-made" executives (Goll and Rasheed, 2005). Scholars have reported an influence of boards' characteristics on the strategic decision making process (Tushman and Romanelli, 1985; Bantel, 1993; Smith et al., 1994). Previous studies have concluded that the top management team's level of education is related to rationality (Hambrick and Mason, 1984; Wiersema and Bantel, 1992; Bantel and Jackson, 1989). Others (e.g. Hambrick and Mason, 1984; Papadakis, 2006) found that educated executives take hierarchical decentralised decisions. The findings of our study indicate an association between the executives' educational level and the strategic decision-making process of financial reporting and hierarchical decentralisation. In the same vein, Papadakis, Lioukas and Chambers (1998) argue that education level is positively associated with financial reporting. Educational level shows the degree of people's information analysis (Dollinger, 1984). Educated CEOs are likely to demand detailed information and extensive financial reporting (Bantel, 1993). This suggests that education might also be associated with more financial reporting, more co-ordination devices and more participation in the strategic decision-making. The fact that the educational level of Greek executives influences the strategic decision-making process might be explained by the dramatic changes that have been occurred in the education system in Greek the last decades. Universities have incorporated in their curriculum several courses in business administration and marketing. Also, many foreign business schools and other academic institutions are operating in Greece. Various EU programmes encourage the exchange of students and researchers and the cross fertilisation of ideas concerning management practices. In our days, the majority of Greek executives have received formal graduate and postgraduate education in Greece or abroad (Bourantas and Papadakis, 1997). 
The second hypothesis suggests that the educational specialty of Greek directors is associated with financial reporting and hierarchical decentralisation in the strategic decision-making processes. This hypothesis is actually an expansion of the previous one, aiming to investigate the effect of demographic characteristics on different forms of strategic decision-making process. More specifically, it investigates the impact of different educational disciplines on financial reporting and on hierarchical decentralisation. Apart from educational level, executives with different types of education are supposed to develop different problem-solving skills (Hitt and Tyler, 1991). Executives with formal education training in sciences and engineering have a better understanding of a company's technological base and are more likely to establish cooperative opportunities (Tyler and Steensma, 1998). Heilmeier (1993) suggested that technically trained executives have technical knowledge and are able to predict, comprehend and anticipate long-term change by identifying opportunities.

However, executives with only a formal management education are more likely to pursue short-term performance goals at the expense of innovation and long-term asset building compared to executives with other educational backgrounds (Hambrick and Mason, 1984). They claimed that business schools are not effective at developing risk-taking tendencies compared to technical schools that are risk-averse oriented. In summary, executives with technical education emphasise more on opportunities rather than on threats (Tyler \& Steensma, 1998). The empirical findings from Greek listed organisations revealed that the educational specialty of executives does not play a predominant role on specific strategic decision-making processes. Greek executives in listed organisation in the Athens Stock Exchange might come from various educational backgrounds and not from a particular one in order to be able to identify the explanatory power of a certain educational specialty on the firms' strategic decision-making processes.

The final hypothesis suggests that the executives' functional background is associated with the strategic decision-making processes of financial reporting and hierarchical decentralisation. The functional background of board members has been distinguished into two broad categories: the "output" and the "throughput" functions. The "output" functions includes functional areas relating to marketing, sales, merchandising as well as product research and development $(\mathrm{R} \& \mathrm{D})$ whereas the "throughput" functions include areas of productions/operations, engineering, finance and accounting. Our research findings derived from GLM analysis suggest that functional background affects only the strategic decisions of financial reporting. Apart from financial reporting, the findings do not provide any support for this hypothesis.

Functional background is regarded as a lens through which business situations are viewed (Guthrie and Datta, 1997), the way in which problems are defined (Dearborn and Simon, 1958). Hambrick and Mason (1984) have distinguished functional background into two broad categories the "output" functions which focus on opportunities and the "throughput" functions which focus on transformation process. This classification provides a linkage between functional background and organisational decision-making. The organisation's strategy partly determines the types of functional background that are essential for the firm's success (Hitt, Ireland and Palia, 1982). Technology oriented companies encourage the appointment of executives whose functional expertise is related to the firm's success (Datta and Guthrie, 1994). Executives with "output" background tend to have greater ambiguity and less control whereas those with "throughput" background tend more to control (Herrmann and Datta, 2002). Throughput backgrounds are important in industries which are characterized by high capital intensity or concentration and lower growth (Rajagopalan and Datta, 1996). The findings revealed an association between the managerial functional background and financial reporting. Greek managers adopt certain elements of financial reporting in their strategic decision-making process. However, the fact that Greek executives come from various functional backgrounds does not allow us to provide any association between their functional background and the specific strategic decision-making process that they pursue.

\section{CONCLUSIONS}

The paper examines the extent to which certain demographic characteristics of Boards of Directors are related to specific strategic decision-making processes. The results of our study support the view that certain demographic characteristics influence the strategic decision-making process of financial reporting and hierarchical decentralisation. In this study, we found that the educational level and functional background matter in strategic decision-making process, while the educational specialty had no significant influence. The findings suggest that the 
executives' attributes do not provide any insight into how Greek executives take their strategic decisions. Apart from two significant demographic findings on strategic decisions, the aforementioned demographic attributes have no effect on strategic decisions. The findings are novel for a country like Greece. Although we could expect to find that the personal attributes of dominant executives would be influential in the strategic decision-making, the results did not support this argumentation. The lack of CEO dominance over strategic decisions can be explained by the fact that our sample consist of large Greek organisations in which all Board members participate equally in strategic decisions. The decisions are not taken by a single individual but a group of people. Therefore, the demographic characteristics of the board members might be heterogeneous and do not allow us to conclude with the demographic characteristics affect strategic decisions.

The results of this study have to be interpreted bearing in mind some limitations. First, it is the crosssectional and retrospective nature of the study. Second, the companies of our sample represent listed and medium and large organisations in the Athens Stock Exchange and are not necessarily generalisable to specific sectors and countries. Maybe, smaller firms might conclude with different results. Third, the study was focused on specific demographic and strategic decision-making process characteristics, perhaps a different set of managerial attributes and strategic decisions characteristics conclude to different findings. Another limitation is that the questionnaire was filled in by a single respondent of each listed on the ASE firms. Data was collected from a single source (e.g. Chairman, CEO or board member) since they are regarded as the apex of an organisation and the most knowledgeable respondents for this study. Future studies might use multiple respondents per firm in order to minimise effects of systematic response bias.

\section{Suggestions for Future Research}

Finally, we would like to point out some avenues for future research. First, the study has focused on few demographic characteristics. The use of a different set of managerial demographic as well as board composition characteristics might conclude with more interesting findings. Second, this study examined the effect of Boards of Directors' characteristics on strategic decisions. Another promising avenue of research is to examine the determinants of strategic decision-making processes from the environmental determinism perspective. Third, this study examined the effect of managerial attributes on two strategic decisions. It will be interesting to investigate their effect on other strategic decision-making characteristics such as rule formalisation, lateral communication, comprehensiveness/rationality, politicization. Finally, it will be interesting to examine how certain strategic decision-making processes contribute to organisational performance.

\section{AUTHOR INFORMATION}

Dr. Maria Elisavet Balta is a Lecturer at Brunel Business School. She holds a PhD in Management Studies and a MSc in Human Resources and Employment Relations from Brunel Business School and a Bachelor degree in Business Administration from the American College of Greece. She is a member of BRESE (Brunel Research in Enterprise, Innovation, Sustainability, and Ethics). Her research interests are in the area of international business, strategic management, and corporate governance in private and public sector organisations.

Professor Adrian Woods is Assistant Head of Brunel Business School. Prior to this he was Dean of Brunel's Graduate School and Dean of the Faculty of Social Sciences. He joined Brunel in 1993 to establish the Department of Management Studies. He has degrees in Economics, Sociology and his PhD was in Psychology. He is a Fellow of both the Royal Society of Arts and the Royal Statistical Society. He has work extensively as a consultant for several large companies and the European Union on business development.

Professor Keith Dickson is currently Deputy Head (Research) \& Professor of Technology Management at Brunel Business School, Brunel University where he was first appointed as lecturer in 1990 following previous academic posts at Kingston University and Aston University. He co-founded BRESE, (Brunel Research in Enterprise, Innovation, Sustainability and Ethics) at Brunel in 2001. Professor Dickson has published widely in the fields of technology management, entrepreneurship and innovation studies as a result of many research projects on such topics as, 'Teleworking in SMEs', 'Intellectual Property Rights Protection in Textiles', 'Social Capital in SMEs', and 'New Product Development Networks'. 


\section{REFERENCES}

1. Aldrich, H. E. and Pfeffer, J., Environments of Organizations, in Inkeles, A. (Eds), Annual Review of Sociology, Palo Alto, CA, Vol. 2 pp.79-105, 1976

2. Andersen, T. J., Strategic Planning, Autonomous Actions and Corporate Performance, Long Range Planning, Vol. 33, No.2, pp. 184-200, 2000

3. $\quad$ Andrews, K. R., The Concept of Corporate Strategy, Dow Jones-Irwin, Homewood, IL., 1971

4. Ansoff, H. I., Corporate Strategy. New York: McGraw-Hill, 1965

5. Bantel, K., Top Team, Environment and Performance Effects on Strategic Planning Formality, Group and Organization Management, Vol. 18, No. 4, pp. 436-458, 1993

6. Bantel, K. and Jackson, S., Top Management and Innovations in Banking: Does the Composition of the Top Management Team Make a Difference?, Strategic Management Journal, Vol. 10, Special Issue, pp. 107-124, 1989

7. Bateman, T. S. and Zeithaml, C., The Psychological Context of Strategic Decisions: A Model and Convergent Experimental Findings, Strategic Management Journal, Vol. 10. No. 1, pp. 59-74, 1989

8. Bourantas, D., Anagnostelis, J., Mantes, Y. and Kefalas, G., The Influence of the Socio-Cultural Environment on Greek Management, Report, General Secretariat for Research and Development, 1987

9. Bourantas, D. and Papadakis, V., Greek Management: Diagnosis and Prognosis, International Studies of Management and Organization, Vol. 26, No.3, pp.13-32, 1997

10. Bryson, J. M. and Bromiley, P., Critical Factors Affecting the Planning and Implementation of Major Projects, Strategic Management Journal, Vol. 14, No. 5, pp. pp. 319-337, 1993

11. Carpenter, M. A. and Fredrickson, J. W., Top Management Teams, Global Strategic Posture, and the Moderating Role of Uncertainty, Academy of Management Journal, Vol. 44, No.3, pp. 533-545, 2001

12. Chandler, A. D., Strategy and Structure: Chapters in the History of the American Industrial Enterprise. Cambridge MIT Press, 1962

13. Child, J., Organisational Structure, Environment and Performance: The Role of Strategic Choice, Sociology, Vol. 6, No. 1, pp. 1-22, 1972

14. Cyert, R. M. and March, J. G., A Behavioural Theory of the Firm, Englewood Cliffs, NJ: Prentice Hall, 1963

15. Datta, D. and Guthrie, J., Executive Succession: Organisational Antecedents of CEO Characteristics”, Strategic Management Journal, Vol.15, No. 7, pp. 569-577, 1994

16. Dean, J. W. and Sharfman, M.P., Does Decision Process Matter? A Study of Strategic Decision-Making Effectiveness, Academy of Management Journal, Vol. 39, No. 2, pp. 369-396, 1996

17. Dearborn, C. and Simon, H., Selective Perception: A Note on the Department Identifications of Executives, Sociometry, Vol. 21, pp.140-144, 1958

18. Dollinger, M., Environmental Boundary Spanning and Information Processing Effects on Organizational Performance, Academy of Management Journal, Vol. 27, No. 2, pp. 351-68, 1984

19. EEDE, The Management Practice in Greek Enterprises. Athens: Greek Management Association, 1986

20. Elbanna, S., Strategic Decision-Making: Process Perspectives, International Journal of Management Review, Vol. 8, No. 1, pp. 1-20, 2006

21. Elbanna, S., Child, J., The Influence of Decision, Environmental and Firm Characteristics on the Rationality of Strategic Decision-Making, Journal of Management Studies, Vol. 44 No.4, pp.561-91, 2007

22. Finkelstein, S. and Hambrick, D., Top Management Team Tenure and Organizational Outcomes: The Moderating Role of Managerial Discretion, Administrative Science Quarterly, Vol. 35, No.3, pp. 484-503, 1990

23. Finkelstein, S. and Hambrick, D., Strategic Leadership: Top Executives and their Effects on Organisations, Minneapolis, St. Paul: West Publishing Company, 1996

24. Ginsberg, A., Measuring and Modelling Changes in Strategy: Theoretical Foundations and Empirical Directions, Strategic Management Journal, Vol. 9, No. 6, pp. 559-575, 1988

25. Goll, I. and Rasheed, A., The Relationship between Top Management Demographic Characteristics, Rational Decision Making, Environmental Munificence and Firm Performance, Organization Studies, Vol. 26, No. 7, pp. 999-1023, 2005

26. Govindarajan, V., Implementing Competitive Strategies at the Business Unit Level: Implications of Matching Managers to Strategies, Strategic Management Journal, Vol. 10, No.3, pp.251-269, 1989 
27. Guthrie, J.P. and Datta, D., Contextual Influence on Executive Selection: Firm Characteristics and CEO Experience, Journal of Management Studies, Vol.34, No.4, pp.537-560, 1997

28. Hambrick, D.C. and Mason, P.A., The Organisation as a Reflection of its Top Managers, Academy of Management Review, Vol. 9, No. 2, pp. 193-206, 1984

29. Hannan, M. T. and Freeman, J. H., The Population Ecology of Organizations, American Journal of Sociology, Vol. 82, No. 5, pp. 929-964, 1977

30. Heilmeier, G., Rooms for Whom at the Top? Promoting Technical Literacy in Executive Suite, ResearchTechnology Management, Vol. 36, No. 6, pp.27-32, 1993

31. Herrmann, P. and Datta, D., CEO Successor Characteristics and the Choice of Foreign Market Entry Mode: An Empirical Study, Journal of Financial Business Studies, Vol. 33, No. 3, pp. 551-569, 2002

32. Herrmann, P. and Datta, D. K., CEO Experiences: Effects on the Choice of FDI Entry Mode, Journal of Management Studies, Vol. 43, No. 4, pp. 755-778, 2006

33. Hickson, D. J., Butler, R. J, Cray, D., Mallory, G. R. and Wilson, D.C., Top Decisions: Strategic DecisionMaking in Organisations. Basil Blackwell, Oxford, 1986

34. Hitt, M. and Tyler, B., Strategic Decision Models: Integrating Different Perspectives, Strategic Management Journal, Vol.12, No.5, pp. 327-351, 1991

35. Hitt, M., Ireland, R. and Palia, K., Industrial Firms' Grand Strategy and Functional Importance: Moderating Effects on Technology and Uncertainty, Academy of Management Journal, Vol.25, No.2, pp.265-298, 1982

36. Hitt, M. A and Ireland, R.D., Corporate Distinctive Competence, Strategy, Industry and Performance, Strategic Management Journal, Vol.6, No.3, pp.273-93, 1985

37. Hofer, C. W., Toward a Contingency Theory of Business Strategy, Academy of Management Journal, Vol. 18, No. 4, pp. 785-810, 1975

38. Hofstede, G., Culture's Consequences: International Differences in Work-Related Values, Sage, Beverly Hills, CA, 1980

39. Hofstede, G., Measuring Hierarchical Power Distance in Thirty-Seven Countries, Brussels, European Institute for Advanced Studies in Management, 1976

40. Holland, J. L., Making Vocational Choices: A Theory of Careers, Prentice-Hall, Englewood Cliffs, N. J., 1973

41. Ireland, R.D. and Miller, C.C., Decision-Making and Firm Success, Academy of Management Executive, Vol. 18, No.4, pp. 8-12, 2004

42. Kanellopoulos, K. C., Personnel Management: The Human Side of Management in Greece, Athens: Papazisis, 1991

43. Kline, P., The Handbook of Psychological Testing, $2^{\text {nd }}$ Ed. London: Routledge, 1999

44. Langley, A., Patterns in the Use of Formal Analysis in Strategic Decisions, Organization Studies, Vol. 11, No. 1, pp. 17-45, 1990

45. Lewin, A. Y. and Stephens, C. U., CEO Attributes as Determinants of Organization Design: An Integrated Model, Organization Studies, Vol. 15, No. 2, pp. 183-212, 1994

46. Lieberson, S. and O'Connor, J. F., Leadership and Organizational Performance: A Study of Large Corporations, American Sociological Review, Vol. 37, No. 2, pp. 117-130, 1972

47. Lyles, M. A. and Mitroff, J. I., Organizational Problem Formulation: An Empirical Study, Administrative Science Quarterly, Vol. 25, No. 1, pp. 102-119, 1980

48. March, P., Barwise, P., Thomas, K. and Wensley, R., Managing Strategic Investment Decisions in Large Diversified Companies. London Business School, Centre for Business Strategy, 1988

49. Mead, R., International Management: Cross Cultural Dimensions, Blackwell Publishing, Cambridge, MA., 1994

50. Michael, J. G. and Hambrick, D.C., Diversification Posture and Top Management Team Characteristics, Academy of Management Journal, Vol. 35, No.1, pp. 9-37, 1992

51. Miller, D. and Toulouse, J. M., Chief Executive Personality and Corporate Strategy and Structure in Small Firms, Management Science, Vol. 32, No.11, pp. 1389-1409, 1986

52. Mintzberg, H., Raisinghani, D. and Theoret, A., The Structure of Unstructured Decision Processes, Administrative Science Quarterly, Vol. 21, No.2, pp. 246-275, 1976

53. Papadakis, V., Do CEOs Shape the Process of Making Strategic Decisions: Evidence from Greece, Management Decision, Vol. 44, No. 3, pp. 367-394, 2006 
54. Papadakis, V. M. and Barwise, P., What Can We Tell Managers About Making Strategic Decisions? In Papadakis, V. M. and Barwise, P. (Eds), Strategic Decisions. London: Kluwer, 267-87, 1997

55. Papadakis, V.M, Lioukas, S. and Chambers, D., Strategic Decision-Making Processes: The Role of Management and Context, Strategic Management Journal, Vol. 19, No. 2, pp. 115-147, 1998

56. Papadakis, V. M. and Barwise, P., Research on Strategic Decisions: Where Do We Go From Here? in Papadakis V. and Barwise, P. (Eds), Strategic Decisions, Kluwer Academic Publishers, Boston, MA, p. 289-302, 1998

57. Papadakis, V. M. and Barwise, P., How Much Do CEOs and Top Managers Matter in Strategic DecisionMaking?, British Journal of Management, Vol. 13, No, 1, pp. 83-95, 2002

58. Papalexandris, N., Factors Affecting Management Staffing and Development: the Case of Greek Firms, European Management Journal, Vol. 6, No. 1, pp. 67-72, 1988

59. Penning, J.M., Introduction: On the Nature and Theory of Strategic Decisions. In Pennings, J.M. (Ed.), Organisation Strategy and Change. San Francisco: Jossey-Bass, pp. 1-34, 1985

60. Pfeffer, J., Organisational Demography. In Research in Organisational Behaviour, ed. L.L. Cummings and B.M. Staw. Vol. 5:299-357. Greemwich, Conn: JAI Press, 1983

61. Rajagopalan, N. and Datta, D., K., CEO Characteristics: Does Industry Matter?, Academy of Management Journal, Vol. 39, No. 1, pp. 197-215, 1996

62. Rajagopalan, N., Rasheed, A. M. A. and Datta, D. K., Strategic Decision Processes: Critical Review and Future Directions, Journal of Management, Vol. 19, No. 2, pp. 349-384, 1993

63. Schwenk, C.R., The Essence of Strategic Decision Making. Lexington, MA: Lexington Books, 1988

64. Smith, K., Smith, K, Olian, J., Sims, J, O’Bannon, D. and Scully, J., Top Management Team Demography and Process: The Role of Social Integration and Communication, Administrative Science Quarterly, Vol. 39, No. 3, pp. 412-438, 1994

65. Smith, M. and White, M. C., Strategy, CEO Specialization, and Succession. Administrative Science Quarterly, Vol. 32, No. 2, pp. 263-280, 1987

66. Stahl, M. J. and Grigsby, D. W., Strategic Management for Decision Making. Boston: PWS-Kent 14601482, 1992

67. Stein, J., Contextual Influence on Strategic Decision Methods, Ph.D. Dissertation. University of Pennsylvania, 1980

68. Thomas, A. S., Litschert, R.J. and Ramaswamy, K., The Performance Impact of Strategy-Manager Coalignment: An Empirical Examination, Strategic Management Journal, Vol.12, No. 7, pp. 509-522, 1991

69. Triandis, H. C., Vassiliou, V. and Nassiakou, M., Three Cross-Cultural Studies of Subjective Culture, Journal of Personality and Social Psychology, Monograph Supplement, Part 2, pp.1-42, 1968

70. Tushman, M. L. and Romenelli, E., Organisation Evolution: A Metamorphosis Model of Convergence and Reorienation, In B. M. Staw \& L. L. Cummings (eds.), Research in Organizational Behavior, Vol. 7, No.2, pp. 171-222, 1985

71. Tyler, B. A and Steensma, K., The Effects of Executives' Experience and Perceptions on their Assessment of Potential Technological Alliances, Strategic Management Journal, Vol.19, No. 10, pp.939-965, 1998

72. Westphal, J.D. and Fredrickson, J. W., Who Directs Strategic Change? Director Experience, the Selection of New CEOs and Change in Corporate Strategy, Strategic Management Journal, Vol. 22, No. 12, pp. 1113-1137, 2001

73. Wiersema, M. F. and Bantel, K. A., Top Management Team Demography and Corporate Strategic Change, Academy of Management Journal, Vol. 35, No.1, pp. 91-121, 1992 


\section{APPENDIX}

\begin{tabular}{|l|c|c|c|}
\hline \multicolumn{1}{|c|}{ Table 1: Principal Component Analysis with a Varimax Rotation } \\
\hline Construct & No. of Factors & No. of Variables & $\begin{array}{c}\text { Cronbach } \\
\text { Alpha }\end{array}$ \\
\hline Strategic Decision-Making Process & 2 & 10 & .818 \\
\hline Financial Reporting & 1 & 5 & .706 \\
\hline Hierarchical Decentralization & 1 & 5 & \\
\hline
\end{tabular}

Table 2: Summary of Factor Loading

\begin{tabular}{|l|l|}
\hline \multicolumn{2}{|c|}{ Table 2: Summary of Factor Loading } \\
\hline Financial Reporting Indicators & $\mathbf{. 8 4 5}$ \\
\hline Use of Net Present Value as Capital Budgeting Method & $\mathbf{. 8 1 9}$ \\
\hline Incorporation of Strategic Decision & $\mathbf{. 7 6 6}$ \\
\hline Inclusion of Pro-Forma Financial Statements & $\mathbf{. 6 9 9}$ \\
\hline Detailed Cost Studies & $\mathbf{. 6 8 8}$ \\
\hline Use of Internal Rate of Return (IRR) as Capital Budgeting Method & 2.933 \\
\hline Eigenvalue for FINREP & 58.654 \\
\hline \% variance explained by FINREP & \\
\hline Hierarchical Decentralisation & $\mathbf{. 8 5 7}$ \\
\hline First level Directors & $\mathbf{. 8 3 4}$ \\
\hline Middle Level Management & $\mathbf{. 6 7 4}$ \\
\hline Lower Level Management & $\mathbf{. 6 5 7}$ \\
\hline Chief Executive Officer & $\mathbf{. 4 6 5}$ \\
\hline Owner/Shareholders & 2.530 \\
\hline Eigenvalue for HIERDECENT & 50.60 \\
\hline$\%$ variance explained by HIERDECENT & \\
\hline
\end{tabular}

Table 3: Significance Levels of Relationships of Demographic Characteristics of Boards of Directors' and Strategic

\begin{tabular}{|l|c|c|}
\multicolumn{1}{|c|}{ Source } & $\begin{array}{c}\text { Sig. level } \\
\text { for }\end{array}$ & $\begin{array}{c}\text { Sig. level } \\
\text { for }\end{array}$ \\
& Financial Reporting & Hierarchical Decentralisation \\
\hline Educational Level BoDs & $\mathbf{. 0 1 7}$ & $\mathbf{. 0 0 5}$ \\
\hline Educational Specialty of BoDs & .798 & .958 \\
\hline Functional Background of BoDs & $\mathbf{. 0 1 2}$ & .371 \\
\hline
\end{tabular}

